\title{
"The adjustment speeds of short-run real estate investment trust (REIT) and corresponding stock returns in the USA and Australia"
}

\begin{tabular}{ll} 
AUTHORS & $\begin{array}{l}\text { Hao Fang } \\
\text { Yen-Hsien Lee } \\
\text { Jen-Sin Lee } \\
\text { Wei-Jui Chen }\end{array}$ \\
\hline ARTICLE INFO & $\begin{array}{l}\text { Hao Fang, Yen-Hsien Lee, Jen-Sin Lee and Wei-Jui Chen (2017). The } \\
\text { adjustment speeds of short-run real estate investment trust (REIT) and } \\
\text { corresponding stock returns in the USA and Australia. Investment Management } \\
\text { and Financial Innovations, 14(3), 173-188. doi:10.21511/imfi.14(3-1).2017.02 }\end{array}$ \\
\hline DOI & http://dx.doi.org/10.21511/imfi.14(3-1).2017.02 \\
\hline RELEASED ON & Monday, 30 October 2017 \\
\hline RECEIVED ON & Wednesday, 09 August 2017 \\
\hline ACCEPTED ON & Wednesday, 25 October 2017 \\
\hline LICENSE & $\begin{array}{l}\text { (cc) EY-No } \\
\text { This work is licensed under a Creative Commons Attribution-NonCommercial } 4.0\end{array}$ \\
\hline JOURNAL & "Investment Management and Financial Innovations" \\
\hline ISSN PRINT & \begin{tabular}{l}
$1810-4967$ \\
\hline ISSN ONLINE
\end{tabular} \\
\hline PUBLISHER & $1812-9358$ \\
\hline FOUNDER & LLC “Consulting Publishing Company "Business Perspectives" \\
\hline LLC “Consulting Publishing Company “Business Perspectives"
\end{tabular}

NUMBER OF REFERENCES

31
NUMBER OF FIGURES

0

\section{ニ:-}

NUMBER OF TABLES

7

(C) The author(s) 2023. This publication is an open access article. 


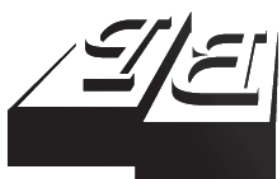

BUSINESS PERSPECTIVES

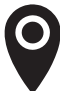

LLC "CPC "Business Perspectives" Hryhorii Skovoroda lane, 10, Sumy, 40022, Ukraine

www.businessperspectives.org

Received on: $9^{\text {th }}$ of August, 2017 Accepted on: $25^{\text {th }}$ of October, 2017

(C) Hao Fang, Yen-Hsien Lee, Jen-Sin Lee, Wei-Jui Chen, 2017

Hao Fang, Department of Assets and Property Management, Hwa Hsia University of Technology, Taiwan.

Yen-Hsien Lee, Department of Finance, Chung Yuan Christian University, Taiwan.

Jen-Sin Lee, Department of Finance, I-Shou University, Taiwan.

Wei-Jui Chen, corresponding author, Department of Finance, Chung Yuan Christian University, Taiwan.

\section{(ㄷ)(1) (8)}

This is an Open Access article, distributed under the terms of the Creative Commons Attribution-NonCommercial 4.0 International license, which permits re-use, distribution, and reproduction, provided the materials aren't used for commercial purposes and the original work is properly cited.
Hao Fang (Taiwan), Yen-Hsien Lee (Taiwan), Jen-Sin Lee (Taiwan),

Wei-Jui Chen (Taiwan)

\section{THE ADJUSTMENT SPEEDS OF SHORT-RUN REAL ESTATE INVESTMENT TRUST (REIT) AND CORRESPONDING STOCK RETURNS IN THE USA AND AUSTRALIA}

\begin{abstract}
This study first uses the non-linear co-integration with structural breaks by Gregory and Hansen (1996) to examine whether non-linear co-integration exists between real estate investment trusts (REITs) and corresponding stock markets in the United States and Australia. Second, the authors employ the smooth transition vector-error correction model (STVECM) including the generalized autoregressive conditional heteroskedasticity $(\mathrm{GARCH})$ model to separately explore the adjustment efficiencies of non-linear short-run REIT and corresponding stock return dynamics, as well as respective REIT return dynamics when the long-run disequilibrium occurs. The results show that a structural break cointegration exists between the equity and mortgage REITs and stock markets in the US, between the REITs and stock markets in the Australia and between the REIT markets in both the US and Australia. When there are large positive and negative deviations of STVECM, the adjustment speed of reverting to equilibrium of the S\&P 500 index is greater than that of the Mortgage REIT index. However, when there are large positive (negative) deviations of STVECM, the adjustment speed of reverting to equilibrium of the Australian REIT (stock) index is greater, and that of the Australian REIT (US REIT) index is greater. In addition, by using a non-linear Granger causality test by Hiemstra and Jones (1994), the authors find that credit price effects exist between the US for each type of REIT and stock markets regardless of large positive or negative deviations (or returns) in STVECM (or STVAR). However, there is a feedback effect exists between the REITs and the stock markets in Australia.
\end{abstract}

\section{Keywords REITs, STVECM, structural break co-integration, nonlinear Granger causality}

\section{JEL Classification C22, G11, L85, D53, C58, G14}

\section{INTRODUCTION}

As of December 2010, the global market capitalization of REITs has surpassed US\$ 800 billion, with nearly 500 fund management units. Thus, REITs have become another favorite choice among investors besides the stock market ${ }^{1}$. Since real estate properties can preserve value while REITs increase liquidity and financial transparency, investors who previously invested only in highly liquid and profitable stocks are now including an increasing number of real-estate related securities into their portfolios to diversify their investment risk $^{2}$. Considering that the effect to diversify risk by investing in the real estate market of different countries may not be inferior to the effect of investing in the stock and real estate markets, this study also examines the real estate price movements of two different countries and the impact they may have on the investment strategy of investors.

\footnotetext{
The global market capitalization of REITs totalled only US\$ 10 billion in early 1990s.

2 According to portfolio theory of Markowitz (1952), investors can reduce their portfolio risk by increasing their investment in commodities with lower coefficient correlation.
} 
Most literatures have confirmed the co-integration between the real estate and stock markets (Tuluca et al., 2000; Liow \& Yang, 2005; Hui \& Yue, 2006). If nonlinear characteristics significantly exist in the time series, the testing power of a traditional linear model may abruptly drop. Considering that the REIT index and corresponding stock index may change over time in a long-term time series, this study uses the residualbased test for co-integration with structural breaks proposed by Gregory and Hansen (1996) to analyze the time-series co-integration between the REIT indices and corresponding stock indices. Wilson and Okunev (1997) found that a non-linear relationship exists between the real estate and stock markets. However, the extent of their mean reversion was quite slow and deviations between the two markets could be prolonged. Subsequently, Wilson and Okunev (1999) used fractional co-integration to find no co-memories between the stock and property markets in the United States and United Kingdom, but they found some evidence of long co-memories in Australia on either side of the 1987 in spite of no co-memory during the entire period. By using the non-parametric rank test, $\mathrm{Su}$ (2011) examined whether a non-linear long-run equilibrium exists between the real estate and stock markets in western European countries and his result demonstrated strong evidence for non-linear adjustments when there was deviation from a long-run equilibrium. In addition, by utilizing the threshold auto-regressive (TAR) model, Su et al. (2011) tested whether a long-run relationship between the real estate and stock markets in European countries existed, and they found that the dynamics reverting to a long-run equilibrium did follow non-linear adjustments with a specific threshold value.

Considering that structural break may lead to a non-linear relationship between the real estate and stock markets, this study adopts the non-linear model to analyze the respective behaviors of short-term mean reversion for the two markets when they deviate from the long-run equilibrium relationship. The phenomenon of non-linear mean reversion between each real estate market and stock market does not necessarily follow the results of long memory. However, the theory of interaction between noise and arbitrage traders have proposed that arbitrageurs must be aware of the potential for noise traders in order to drive returns further away from equilibrium before correction. To be more specific, the dynamics governing small return deviations from the equilibrium differs at least from the dynamics governing large return deviations. In this case, the smooth transition vector error-correction model (STVECM) should be able to capture the real estate and stock market dynamics with large and small returns and allow the gradual movement between the different regimes. In addition, the high-frequency financial asset prices may fluctuate in clusters. Therefore, after confirming the co-integration relationship (with structural breaks) between the REIT and corresponding stock price indices, this study further explores whether the STVECM with the GARCH model can accurately describe the dynamic adjustments in reverting to long-run equilibrium between the REIT and corresponding stock price indices.

Past literatures have not reached a consistent conclusion on the lead-lag relationship of the stock and real estate markets, which included 'wealth effect' and 'credit price effect'. In regard to the wealth effect, Chau et al. (2000) pointed out that the rise of the S\&P 500 index would result in the decline of Jones Lang LaSalle JLW real-estate price indices in the following season. The results of Oppenheimer and Grissom (1998), Larson (2005) and Chen (2007) showed that stock indices could serve as a leading indicator for the REIT prices and a rapid reversal of the stock market would lead to the same reaction from the REIT markets. The non-linear causality test used by Okunev et al. (2002) found that Australian stock markets had a significant one-way impact on its real estate markets. In regard to credit price effect, Hui and Yue (2006) found that the prices of used houses in Beijing and Shanghai would affect stock indices in Shanghai but the stock indices did not affect the corresponding housing prices. Moreover, some empirical literatures found that there were two-way relationships between stock and real-estate prices or the causal relationships between the two markets only showed in some areas ${ }^{3}$. The empirical study by Green (2002) showed that causality relationships between stock and housing prices did exist in high-priced housing areas but was not significant in areas with low housing prices.

3 The empirical results of Chen and Patel (1998) showed a two-way relationship between stock indices and housing prices and Okunev et al. (2000) found that there were unstable non-linear relationships and two-way Granger causal relationships between real-estate prices and stock prices. 
The traditional vector auto-regression (VAR) model includes linear predictive ability while disregarding the non-linear effects. Based on the concept of nonparametric statistics and correlation integral, this study adopts the nonparametric non-linear Granger causality test proposed by Hiemstra and Jones (1994) to analyze whether there is either a wealth effect or a credit price effect between the stock and REIT prices in the US and Australia, respectively. Meanwhile, we are also interested in finding out whether the REIT indices in the US or Australia would serve as a leading indicator for price movements.

Real estate securitization originated in the US, whose REIT markets include the longest history and a market capitalization ranks first in the world. Australia developed its REITs in 1971, and its market capitalization ranks second in the world ${ }^{4}$. Due to such rankings, investors will simultaneously allocate their investment in both the stock and real estate securitization markets in the US and Australia in order to diversify risk. Therefore, when interest rates becomes lower and inflation becomes rampant, those who simultaneously invest in real estate securitization and stock markets in the US and Australia (or those who make investments in the US and Australian real estate securitization markets) will be eager to know what the lead-lag relationship is between the REIT and stock markets in these areas (or the REIT markets in these two countries). They will also want to know if co-integration with structural breaks exists between the REIT and stock markets in these countries (or the REIT markets in these two countries). When the REIT indices and stock indices (or the REIT indices in these two countries) deviate from their long-run equilibrium respectively, how efficiently can the two indices adjust themselves dynamically and revert to equilibrium? This study further analyses whether co-integration with structural breaks exists between the respective three REIT (i.e., equity, mortgage and hybrid) and stock markets ${ }^{5}$. When the respective REIT indices and stock indices deviate from the long-run equilibrium, how efficiently can the two indices adjust themselves dynamically and revert to equilibrium? Hence, the study will examine the correlation between the stock and real estate securitization markets in the US and Australia in terms of the overall and classified REIT indices. In this case, this study can serve as a good reference for the investors investing in these two regions.

The remainder of this paper is organized as follows. Section 1 describes the data and statistical analysis used in this study and section 2 introduces the methodology. Section 3 analyzes the empirical results and final section presents the conclusions.

\section{DATA AND DESCRIPTIVE ANALYSIS}

\subsection{Data range}

The data range of this study consists of the REIT indices and corresponding stock indices in the US and Australia. The REIT indices in the US include the daily REIT indices for all and the equity, mortgage and hybrid types. The corresponding stock price index in the US is the daily S\&P 500 index. The data employed for Australia includes the daily All REIT index and the All Ordinaries index. Since the beginning of the REIT indices in the US and Australia are different, this study utilises the beginning of the REIT index of each country as the beginning of the REIT index and of the stock price index for each country. Thus, the data for the REIT index and the stock price index in the US extend from 1 January 1999 to 2 February 2011 and those for Australia are from 3 March 2000 to 28 February 2011. In addition, the data for the REIT indices in the US and Australia extend from 3 March 2000 to 28 February 2011. The data source for the REIT indices, as well as the stock price indices employed in this study is from the Datastream database.

4 Australia not only provides the world's most transparent information in the real estate markets, but also enjoys the world's highest proportion of real estate securitization.

5 In accordance with the sources of income, the US REITs can be divided into three main types: equity (whose main sources of income are from rentals); mortgage (whose main sources of income are from interest income); and hybrid (which is a portfolio of rental and interest incomes). 
Table 1. Descriptive statistics of REIT index returns in the US and Australia

\begin{tabular}{|c|c|c|c|c|c|c|c|}
\hline Items & $\begin{array}{l}\text { US all } \\
\text { REITs }\end{array}$ & $\begin{array}{c}\text { US EQUITY } \\
\text { REITs } \\
\end{array}$ & $\begin{array}{c}\text { US MORTGAGE } \\
\text { REITs } \\
\end{array}$ & $\begin{array}{c}\text { US HYBRID } \\
\text { REITS } \\
\end{array}$ & $\begin{array}{c}\text { Aus all } \\
\text { REITs }\end{array}$ & S\&P 500 & Aus ASX \\
\hline Mean & 0.000147 & 0.000183 & -0.000263 & -0.000261 & -0.00012 & $2.42 \mathrm{E}-05$ & 0.000162 \\
\hline Median & 0.000000 & 0.000000 & 0.000000 & 0.000000 & 0.000226 & 0.000146 & 0.000486 \\
\hline Maximum & 0.162366 & 0.168755 & 0.219701 & 0.16378 & 0.080593 & 0.109572 & 0.053601 \\
\hline Minimum & -0.205429 & -0.215324 & -0.192739 & -0.232155 & -0.121282 & -0.094695 & -0.085536 \\
\hline Std. Dev. & 0.019626 & 0.020305 & 0.019555 & 0.02253 & 0.013959 & 0.013294 & 0.010138 \\
\hline Skewness & -0.181449 & -0.195064 & -0.027507 & -0.569542 & -0.90442 & -0.114767 & -0.672606 \\
\hline Kurtosis & 21.08004 & 21.46572 & 26.39837 & 19.77375 & 13.72932 & 10.73365 & 10.33056 \\
\hline \multirow{2}{*}{ Jarque-Bera } & 43207.44 & 45072.46 & 72336.7 & 37345.93 & 13669.13 & 7909.275 & 6413.337 \\
\hline & {$[0.000000]$} & [0.000000] & [0.000000] & [0.000000] & [0.000000] & [0.000000] & [0.000000] \\
\hline LB Q (4) & $111.16^{* * *}$ & $112.76^{* * *}$ & $30.485^{* * *}$ & $29.836 * * *$ & $25.702^{* * *}$ & $34.022 * * *$ & $12.054^{* *}$ \\
\hline LB Q (8) & $128.63^{* * *}$ & $128.73^{* * *}$ & $50.530^{* * *}$ & $40.639 * * *$ & $80.236^{* * *}$ & $43.190^{* * *}$ & $21.990^{* * *}$ \\
\hline
\end{tabular}

Notes: numbers in [ ] indicate the p-value of the Jarque-Bera statistics. ${ }^{\star * *},{ }^{* *}$ and ${ }^{\star}$ denote significance at the $1 \%, 5 \%$ and $10 \%$ levels, respectively.

\subsection{Descriptive statistical analysis of the REIT and stock indices}

The results in Table 1 show that the REIT index return average for equity REITs in the US is significantly higher than that of the other four REITs. However, the results of the standard deviation in Table 1 show that the fluctuations in the Hybrid REIT index return in the US are significantly higher than those in the other four REIT index returns ${ }^{6}$. In addition, the average for S\&P 500 index returns in the US is significantly higher than that for ASX index returns in Australia, which indicates that the average stock index return in the US is significantly higher than that in Australia. The standard deviation in the same table shows that the fluctuations in S\&P 500 index returns in the US is higher than those in ASX index returns in Australia, indicating that the risk of S\&P 500 stock index return in the US is higher. Combing the standard deviations in Table 1, we find that there are significantly greater fluctuations regardless of the REIT index returns or stock index returns in the US, which shows that there is a close relationship between the fluctuations in the REIT index and those in the stock index in the US?.

\section{METHODOLOGY}

\subsection{Nonlinear unit root test}

In order to reinforce the power of the unit root test for the non-linear dynamic adjustments of the REIT and stock indices in the US and Australia, respectively, this study utilizes the non-linear KSS stationarity test by Kapetanios et al. (2003). The goal of the KSS test is to detect the presence of non-stationarity against a non-linear but stationary exponential smooth transition autoregressive (ESTAR) process ${ }^{8}$. Given that $\gamma$ cannot be identified in the null hypothesis, Luukkonen et al. (1988) and Kapetanios et al. (2003) used the first-order Taylor series to approximately estimate

6 Jarque-Bera test results of the five REIT index returns are all significantly different from zero, which indicates that the five REIT index returns in such areas do not conform to normal distribution. As for the Ljung-Box Q test, the five REIT index returns all exhibit the phenomenon of time series autocorrelation.

$7 \quad$ Jarque-Bera test results of the stock price index returns in the US and Australia are significantly different from zero, which indicates that the two stock price index returns do not conform to normal distribution. The Ljung-Box $Q$ test results show that the two stock price index returns in such areas exhibit the phenomenon of time series autocorrelation.

$8 Y_{t}$ is the time series data to be studied. $\varepsilon_{t}$ is the random residual to cope with $\sim$ iid $\left(0, \sigma^{2}\right)$, and $\theta \geq 0$ is the adjustment speed of the exponential smooth transition. In the null hypothesis H0: $\theta=0, Y_{t}$ is a linear unit root process, while in the alternative hypothesis Ha: $\theta>0, Y_{t}$ is a non-linear constant ESTAR process. 
$\left\{1-\exp \left(-\theta Y_{t-1}^{2}\right)\right\}$. The model is expressed as:

$$
\Delta Y_{t}=\gamma \cdot Y_{t-1}\left\{1-\exp \left(-\theta Y_{t-1}^{2}\right)\right\}+\varepsilon_{t} .
$$

For the null hypothesis $\theta=0$, equation (1) can be re-written as:

$$
\Delta Y_{t}=\zeta+\delta \cdot Y_{t-1}^{3}+\sum_{i=1}^{k} \rho_{i} \cdot \Delta Y_{t-i}+\varepsilon_{t},
$$

$t=1,2, \ldots ., T$.

If the estimate does not reject the hypothesis $H_{0}$ : $\delta=0$, the sequence is a unit root; otherwise the sequence is a non-linear constant ESTAR.

The results of the KSS non-linear stationarity test show that all of the REIT indices and corresponding stock price indices in the US, as well as the REIT index and stock price index in Australia are all linear unit roots whose first-order differences are stationary. This confirms that the respective REIT indices and stock price indices are I (1) sequences in such areas.

\subsection{Structure break co-integration test}

Considering the tendency that stock price and house price indices most likely change over time, we use the co-integration test proposed by Gregory and Hansen (1996). This test can be used to analyse non-linear co-integration relationships with structural breaks in time series. First, the traditional co-integration model of housing prices $P_{h t}$ and stock prices $P_{s t}$ is assumed as (3):

$$
P_{s t}=\mu_{1}+\alpha_{1} \cdot P_{h t}+e_{t}, t=1, \cdots, n \text {. }
$$

Nevertheless, it is found that a co-integration relationship may remain for some time and then turn into a new long-term equilibrium relationship. It is therefore required that assumptions of co-integration with structural breaks be changed into an unknown. Furthermore, we consider that structural breaks may occur in both the intercept and the slope. In this case, the dummy variables are established as:

$$
D_{t \tau}=\left\{\begin{array}{l}
0 \text { if } t \leq[n \cdot \tau] \\
1 \text { if } t>[n \cdot \tau]
\end{array} .\right.
$$

Among them, $\tau \in(0,1)$ is the unknown structural break point in the time series. In addition, the structural co-integration model can appear in the following three forms:

Structural breaks occur in the intercept (C):

$$
P_{h t}=\mu_{1}+\mu_{2} \cdot D_{t \tau}+\alpha_{1} \cdot P_{s t}+e_{t} .
$$

Structural breaks occur in both the intercept and time trends $(\mathrm{C} / \mathrm{T})$ :

$$
\begin{gathered}
P_{h t}=\mu_{1}+\mu_{2} \cdot D_{t \tau}+\beta_{t} \cdot t+\alpha_{1} \cdot P_{s t}+e_{t}, \\
P_{h t}=u_{1}+u_{2} \cdot D_{t \tau}+\beta_{t}+\alpha_{1} \cdot P_{s t}+e_{t} .
\end{gathered}
$$

Structural breaks occur in both the intercept and the slope $(\mathrm{C} / \mathrm{S})$ :

$P_{h t}=\mu_{1}+\mu_{2} \cdot D_{t \tau}+\alpha_{1} \cdot P_{s t}+\alpha_{2} \cdot P_{s t} \cdot D_{t \tau}+e_{t} \cdot(7)$

Under the assumption of $\tau \in T$, Gregory and Hansen (1996) utilized the above three models in order to make an ordinary least squares (OLS) estimation for each $\tau$ and to obtain the residuals $\hat{e}_{t \gamma}$. The augmented Dickey-Fuller (ADF) statistics can be used to regress $\Delta \hat{e}_{t \tau}$ on $\hat{e}_{t-1 \tau}$ and $\kappa$ backward differential $\left(\Delta \hat{e}_{t-1 \tau}, \ldots, \Delta \hat{e}_{t-1 \kappa \tau}\right)$ by OLS estimation, in order to obtain the regression coefficients for $\hat{e}_{t-1 \tau}$. The $t$ statistics are ADF $(\tau)=t$ and stat $\left(\hat{e}_{t-1 \tau}\right)$. Its test statistics $\mathrm{ADF}^{*}$ in equation (8) are not the traditional ADF statistics, but the minimum statistics that correspond to specific structural break points defined as:

$$
\mathrm{ADF}^{*}=\inf \operatorname{ADF}(\tau)
$$

The critical value of the test statistic is simulated by Gregory and Hansen (1996) using the response surface function. The simulation is also used in our empirical results to obtain the asymptotically distributed critical value. 


\subsection{Non-linearity test and estimations of the STVECM (STVAR)-GARCH}

In order to review the different return dynamics for both the small and large deviations from the co-movements between the stock and REIT prices in the US and Australia separately, this study applies the STVECM to allow for a smooth transition for return dynamics in different regimes. Meanwhile, we let the residuals in this model follow a GARCH process in order to capture the heterogeneity of the residuals. However, if a cointegration does not exist between the stock and REIT prices in any such location, the study uses the STVAR to smoothly transform the return dynamics in different regimes to capture the different dynamics of the stock and REIT price returns in the lower and higher return regimes. In addition, we let the residuals in the STVAR follow a GARCH process. Thus, the STVECM-GARCH and STVAR-GARCH can be expressed as follows':

$$
\begin{aligned}
& \Delta P_{t}^{h}=\left(\alpha_{0}^{h}+\alpha_{1}^{h} \cdot Z_{t-1}+\sum_{i=1}^{q} \alpha_{i+1}^{h} \cdot \Delta P_{t-i}^{s}+\right. \\
& \left.+\sum_{i=1}^{q} \alpha_{i+1+q}^{h} \cdot \Delta P_{t-i}^{h}\right)+\left(\beta_{0}^{h}+\beta_{1}^{h} \cdot Z_{t-1}+\right. \\
& \left.+\sum_{i=1}^{q} \beta_{i+1}^{h} \cdot \Delta P_{t-i}^{s}+\sum_{i=1}^{q} \beta_{i+1+q}^{h} \cdot \Delta P_{t-i}^{h}\right) \times \\
& \times F\left(Z_{t-d}: \gamma, \tau\right)+\varepsilon_{t}^{h}, \\
& \Delta P_{t}^{s}=\left(\alpha_{0}^{s}+\alpha_{1}^{s} \cdot Z_{t-1}+\sum_{i=1}^{q} \alpha_{i+1}^{s} \cdot \Delta P_{t-i}^{s}+\right. \\
& \left.+\sum_{i=1}^{q} \alpha_{i+1+q}^{s} \cdot \Delta P_{t-i}^{h}\right)+\left(\beta_{0}^{s}+\beta_{1}^{s} \cdot Z_{t-1}+\right. \\
& \left.+\sum_{i=1}^{q} \beta_{i+1}^{s} \cdot \Delta P_{t-i}^{s}+\sum_{i=1}^{q} \beta_{i+1+q}^{s} \cdot \Delta P_{t-i}^{h}\right) \times \\
& \times F\left(Z_{t-d}: \gamma, \tau\right)+\varepsilon_{t}^{s},
\end{aligned}
$$

9 In equation (9), where $\Delta P_{t}^{h}$ and $\Delta P_{t}^{s}$ separately represent the REIT and stock price returns, $Z_{t-1}=\left(P_{t-1}^{s}-c_{0}-c_{1} \cdot P_{t-1}^{h}\right)$ represents the error correction term between the REIT price $P_{t}^{h}$ and the stock price $P_{t}^{s}$. $h_{h, t}, h_{s, t}$, represents the conditional heterogeneous variance of the REIT (stock) return residuals, and $h_{h s, t}$ represents the conditional heterogeneous covariance of the REIT and stock return residuals.

10 Where $Z_{t-d}$ is the transition variable, $\mathrm{d}$ is the optimal lag length and $\Delta r_{t-d}$ represents the change in the monthly deposit interest rate before period $d$. $\gamma$ is the smoothness parameter that measures how quickly the transition occurs from the regime with small deviations to that with large deviations. Finally, $\tau$ is the threshold parameter that determines where the transition occurs.

11 If there is not a co-integration between the REIT prices in the two countries, this study also uses the STVAR-GARCH model to analyze the relationship between the changes in the two REIT prices. However, we do not describe the setting in this particular model.

12 If the STVECM-GARCH in equation (9) is confirmed as STVAR-GARCH, the logistic and exponential types of the transition function are:

$$
F\left(\Delta r_{t-d}: \gamma, \tau\right)=\left\{1+\exp \frac{-\gamma \cdot\left(\Delta r_{t-d}-\tau\right)}{\sigma_{\Delta_{t-d}}}\right\}^{-1}, \gamma>0 \text { and } F\left(\Delta r_{t-d}: \gamma, \tau\right)=1-\exp \frac{-\gamma \cdot\left(\Delta r_{t-d}-\tau\right)^{2}}{\sigma_{\Delta_{t-d}}}, \gamma>0 \text {. }
$$




$$
F\left(Z_{t-d}: \gamma, \tau\right)=1-\exp \frac{-\gamma \cdot\left(Z_{t-d}-\tau\right)^{2}}{\sigma_{Z_{t-d}}},
$$

$$
\gamma>0 .
$$

Let us take the STVECM between the stock and REIT prices for example. Equation (9) with transition function (10) is called the logistic STVECM (or LSTVECM), and the LSTVECM represents the different dynamics for the two return regimes with a smooth transition function $F\left(Z_{t-d}: \gamma, \tau\right)=0 \sim 1$ as $Z_{t-d}=-\infty \sim+\infty{ }^{13}$. When $\gamma \rightarrow+\infty, F\left(Z_{t-d}: \gamma, \tau\right) \rightarrow 0$ represents the regime of large negative deviations if the stock prices are significantly lower than the REIT prices for $Z_{t-d}<<$ and $F\left(Z_{t-d}: \gamma, \tau\right) \rightarrow 1$ represents the regime of large positive deviations if the stock prices are significantly higher than the REIT prices for $Z_{t-d}>>\tau^{14}$. Equation (9) with transition function (11) is called the exponential STVECM (or ESTVECM). The ESTVECM means that there are different dynamics in the transition regime, but similar dynamics in the extreme regimes since $F\left(Z_{t-d}: \gamma, \tau\right) \rightarrow 1$ as $\left|Z_{t-d}\right| \rightarrow+\infty{ }^{15}$.

The non-linear STVECM is only identified under the alternative hypothesis of non-linearity $H_{0}$ : $\gamma>0$. Rather than the null hypothesis of linearity $H_{0}: \gamma=0$. In addition, Luukkonen et al. (1998) proposed that it is feasible to replace $F\left(Z_{t-d}: \gamma, \tau\right)$ with its third-order Taylor approximation of $\gamma=0$. In order to directly examine whether the parameters of the third-order Taylor series in equation (12) are 0 , this study utilizes the Wald test as follows ${ }^{16}$ :

$$
\begin{aligned}
& \Delta P_{t}^{h}=\pi_{10}+\pi_{11}^{\prime} \cdot W_{t}+\kappa_{11}^{\prime} \cdot W_{t}\left(Z_{t-d}\right)+ \\
& +\kappa_{12}^{\prime} \cdot W_{t}\left(Z_{t-d}\right)^{2}+\kappa_{13}^{\prime} \cdot W_{t}\left(Z_{t-d}\right)^{3}+\eta_{1 t}, \\
& \Delta P_{t}^{s}=\pi_{20}+\pi_{21}^{\prime} \cdot W_{t}+\kappa_{21}^{\prime} \cdot W_{t}\left(Z_{t-d}\right)+ \\
& +\kappa_{22}^{\prime} \cdot W_{t}\left(Z_{t-d}\right)^{2}+\kappa_{23}^{\prime} \cdot W_{t}\left(Z_{t-d}\right)^{3}+\eta_{2 t},
\end{aligned}
$$

where

$W_{t}=\left(Z_{t-1}, \Delta P_{t-1}^{s} \ldots, \Delta P_{t-q}^{s}, \Delta P_{t-1}^{h} \ldots, \Delta P_{t-q}^{h}\right)$.

Before estimating the non-linear STVECM, it is necessary to test for linearity using $F\left(Z_{t-d}: \gamma, \tau\right)=0$ for the delay parameter $d$ with the smallest $p$-value. After the delay parameter $d$ is determined, the linearity test is equivalent to the test of the hypothesis:

$H_{0}: \kappa_{11}^{\prime}=\kappa_{12}^{\prime}=\kappa_{13}^{\prime}=\kappa_{21}^{\prime}=\kappa_{22}^{\prime}=\kappa_{23}^{\prime}=0$.

We use the auxiliary regression (14) as follows ${ }^{17}$ :

$$
\begin{aligned}
& \widehat{\varepsilon}_{t}^{h}=\pi_{10}+\pi_{11}^{\prime} \cdot W_{t}+\kappa_{11}^{\prime} \cdot W_{t}\left(Z_{t-d}\right)+ \\
& +\kappa_{12}^{\prime} \cdot W_{t}\left(Z_{t-d}\right)^{2}+\kappa_{13}^{\prime} \cdot W_{t}\left(Z_{t-d}\right)^{3}+v_{1 t}, \\
& \widehat{\varepsilon}_{t}^{s}=\pi_{20}+\pi_{21}^{\prime} \cdot W_{t}+\kappa_{21}^{\prime} \cdot W_{t}\left(Z_{t-d}\right)+ \\
& +\kappa_{22}^{\prime} \cdot W_{t}\left(Z_{t-d}\right)^{2}+\kappa_{23}^{\prime} \cdot W_{t}\left(Z_{t-d}\right)^{3}+v_{2 t},
\end{aligned}
$$

where $\widehat{\varepsilon}_{t}^{h}\left(\widehat{\varepsilon}_{t}^{s}\right)$ is the residual under the null hypothesis of linearity VECM or VAR. Then, we use the Wald test statistic in order to examine the linear versus non-linear STVECM or STVAR. Moreover, this study utilizes a sequence of tests in equation (15) in order to identify whether the LSTVECM or ESTVECM is the suitable model. The null hypothesis for identifying the type of transition is as follows:

13 A logistic transition function allows the STVECM parameters to change monotonically with $Z_{t-d}$.

14 Since $F\left(Z_{t-d}: \gamma, \tau\right)$ is not symmetrical with $\tau$, the LSTVECM can generate asymmetric short-run dynamics.

15 The ESTVECM allows the parameters to change symmetrically about $\tau$ with $Z_{t-d}$.

16 If the STVAR is confirmed, we use the Wald test as shown in the following equation, where $W_{t}=\left(\Delta P_{t-1}^{s} \ldots, \Delta P_{t-q}^{s}, \Delta P_{t-1}^{h} \ldots, \Delta P_{t-q}^{h}\right)$.

$\Delta P_{t}^{h}=\pi_{10}+\pi_{11}^{\prime} \cdot W_{t}+\kappa_{11}^{\prime} \cdot W_{t}\left(\Delta r_{t-d}\right)+\kappa_{12}^{\prime} \cdot W_{t}\left(\Delta r_{t-d}\right)^{2}+\kappa_{13}^{\prime} \cdot W_{t}\left(\Delta r_{t-d}\right)^{3}+\eta_{1 t}$,

$\Delta P_{t}^{s}=\pi_{20}+\pi_{21}^{\prime} \cdot W_{t}+\kappa_{21}^{\prime} \cdot W_{t}\left(\Delta r_{t-d}\right)+\kappa_{22}^{\prime} \cdot W_{t}\left(\Delta r_{t-d}\right)^{2}+\kappa_{23}^{\prime} \cdot W_{t}\left(\Delta r_{t-d}\right)^{3}+\eta_{2 t}$.

17 If the STVAR is confirmed, we use the following auxiliary regression:

$$
\begin{aligned}
& \bar{\varepsilon}_{t}^{h}=\pi_{10}+\pi_{11}^{\prime} \cdot W_{t}+\kappa_{11}^{\prime} \cdot W_{t}\left(\Delta r_{t-d}\right)+\kappa_{12}^{\prime} \cdot W_{t}\left(\Delta r_{t-d}\right)^{2}+\kappa_{13}^{\prime} \cdot W_{t}\left(\Delta r_{t-d}\right)^{3}+v_{1 t}, \\
& \widehat{\varepsilon}_{t}^{s}=\pi_{20}+\pi_{21}^{\prime} \cdot W_{t}+\kappa_{21}^{\prime} \cdot W_{t}\left(\Delta r_{t-d}\right)+\kappa_{22}^{\prime} \cdot W_{t}\left(\Delta r_{t-d}\right)^{2}+\kappa_{23}^{\prime} \cdot W_{t}\left(\Delta r_{t-d}\right)^{3}+v_{2 t} .
\end{aligned}
$$


$H_{04}: \kappa_{13}=\kappa_{23}=0$

$H_{03}: \kappa_{12}^{\prime}=\kappa_{22}^{\prime}=0 \mid \kappa_{13}^{\prime}=\kappa_{23}^{\prime}=0$

$H_{02}: \kappa_{11}^{\prime}=\kappa_{21}^{\prime}=0 \mid \kappa_{12}^{\prime}=\kappa_{22}^{\prime}=\kappa_{13}^{\prime}=\kappa_{23}^{\prime}=0$.

If $H_{04}$ is rejected, then the LSTVECM is fitted. If $H_{03}$ is rejected, then the ESTVECM is fitted. If both $H_{04}$ and $H_{03}$ is accepted but $H_{02}$ is rejected, then the LSTVECM should be selected.

\section{THE EMPIRICAL RESULTS}

\subsection{Results of the co-integration test}

As seen in Table 2, Panel A shows that when structural breaks are considered, there is a non-linear co-integration relationship in at least one model test between US Equity REIT or Mortgage REIT indices and the S\&P 500 indices, respectively. Meanwhile, there is a non-linear co-integration relationship in at least one model test between Australian all REIT indices and its ASX stock indices. There is a non-linear co-integration relationship in at least one model test between US all REIT indices and Australian all REIT indices. Moreover, the structural break points of the co-integration between the US various-type REIT indices and the S\&P 500 indices fall during the first half of 1999, while the structural break points of the co-integration between Australian all REIT indices and its stock indices fall in 2002. Furthermore, the structural break points of the co-integration between US all REIT indices and Australian all REIT indices fall in 2007. However, there is no non-linear co-integration relationship between Hybrid REIT and the S\&P 500 stock indices. Thus, this study utilizes the nonlinear cointegrated equilibrium, which does not contain error correction terms that establish the short-run dynamic adjustment model between Hybrid REIT and stock prices.

\subsection{Results of the non-linear test and the STVECM (or STVAR)}

The results of linearity against the non-linear test in Table 3 show significant evidence of non-linearity between the REIT and corresponding stock prices in the US and Australia and between the two REIT prices. In order to determine $d$, we estimate a range of $d$ values $(1 \leq d \leq 6)$, where the $F$ statistics with the minimum $p$-value or the maximum $F$ statistics identify the optimal $d$ value. The results in Table 4 show that $H_{04}$ is rejected for $d=1$ between Equity REIT and the S\&P

Table 2. Structural break co-integration tests for the REIT and stock indices

\begin{tabular}{|c|c|c|c|c|}
\hline Index name & Model design & Statistics & Structural break point & Co-integration \\
\hline \multicolumn{5}{|c|}{ Panel A: US various-type REIT and stock indices } \\
\hline \multirow{3}{*}{$\begin{array}{l}\text { S\&P } 500 \\
\text { EQUITY REITS }\end{array}$} & $\mathrm{C}$ & -4.159 & 1999/3/8 & No \\
\hline & $\mathrm{C} / \mathrm{T}$ & -4.563 & $1999 / 3 / 12$ & No \\
\hline & $\mathrm{C} / \mathrm{S}$ & -4.538 & $1999 / 3 / 19$ & Yes \\
\hline \multirow{3}{*}{$\begin{array}{l}\text { S\&P } 500 \\
\text { HYBRID REITS }\end{array}$} & C & -4.082 & $1999 / 3 / 8$ & No \\
\hline & $\mathrm{C} / \mathrm{T}$ & -4.543 & 1999/3/12 & No \\
\hline & $\mathrm{C} / \mathrm{S}$ & -4.539 & $1999 / 3 / 23$ & No \\
\hline \multirow{3}{*}{$\begin{array}{l}\text { S\&P } 500 \\
\text { MORTGAGE REITS }\end{array}$} & C & -4.314 & $1999 / 3 / 8$ & No \\
\hline & $\mathrm{C} / \mathrm{T}$ & -5.171 & $1999 / 3 / 9$ & Yes \\
\hline & $\mathrm{C} / \mathrm{S}$ & -4.745 & 1999/3/19 & Yes \\
\hline \multicolumn{5}{|c|}{ Panel B: Australian REIT and ASX stock indices } \\
\hline \multirow{3}{*}{$\begin{array}{l}\text { ASX stock index } \\
\text { REIT index }\end{array}$} & $\mathrm{C}$ & -4.005 & $2008 / 7 / 21$ & No \\
\hline & $\mathrm{C} / \mathrm{T}$ & -5.057 & $2002 / 6 / 26$ & Yes \\
\hline & $\mathrm{C} / \mathrm{S}$ & -3.745 & $2008 / 11 / 17$ & No \\
\hline \multicolumn{5}{|c|}{ Panel C: US and Australian REIT indices } \\
\hline \multirow{3}{*}{$\begin{array}{l}\text { US all REIT index } \\
\text { Australian REIT index }\end{array}$} & C & -4.731 & $2007 / 5 / 16$ & Yes \\
\hline & $\mathrm{C} / \mathrm{T}$ & -3.864 & $2008 / 1 / 4$ & No \\
\hline & $\mathrm{C} / \mathrm{S}$ & -4.373 & $2007 / 5 / 18$ & No \\
\hline
\end{tabular}

Note: statistics indicate the $\mathrm{ADF}^{*}$ statistics defined in equation (8). 
Table 3. Nonlinear test

\begin{tabular}{|c|c|c|c|c|c|c|}
\hline d & 1 & 2 & 3 & 4 & 5 & 6 \\
\hline \multicolumn{7}{|c|}{ Panel A: US REIT and S\&P 500 stock indices } \\
\hline \multicolumn{7}{|c|}{$\begin{array}{l}\text { EQUITY REITs and S\&P } 500 \\
\end{array}$} \\
\hline HO F Stat & 63.0314 & 54.2710 & 58.9111 & 57.3745 & 53.3201 & 43.9632 \\
\hline p-value & 0.0000 & 0.0000 & 0.0000 & 0.0000 & 0.0000 & 0.0001 \\
\hline \multicolumn{7}{|c|}{ HYBRID REITs and S\&P 500} \\
\hline HO F Stat & 53.6428 & 31.2420 & 62.1970 & 51.9303 & 28.4243 & 90.2303 \\
\hline $\mathrm{p}$-value & 0.0000 & 0.0018 & 0.0000 & 0.0000 & 0.0048 & 0.0000 \\
\hline \multicolumn{7}{|c|}{ MORTGAGE REITs and S\&P 500} \\
\hline HO F Stat & 33.3900 & 38.2819 & 42.5467 & 37.0605 & 32.8731 & 30.3021 \\
\hline p-value & 0.0041 & 0.0008 & 0.0002 & 0.0012 & 0.0049 & 0.0109 \\
\hline \multicolumn{7}{|c|}{ Panel B: AUS REIT and stock indices } \\
\hline HO F Stat & 30.4290 & 28.6041 & 29.6201 & 34.8241 & 35.5418 & 34.5093 \\
\hline p-value & 0.0105 & 0.0181 & 0.0134 & 0.0026 & 0.0021 & 0.0029 \\
\hline \multicolumn{7}{|c|}{ Panel C: US REIT and S\&P 500 stock indices } \\
\hline HO F Stat & 82.9228 & 111.0763 & 89.4587 & 89.4591 & 93.2141 & 55.2317 \\
\hline p-value & 0.0000 & 0.0000 & 0.0000 & 0.0000 & 0.0000 & 0.0000 \\
\hline
\end{tabular}

Notes: the specification and null hypothesis of the nonlinear STVECM (or STVAR) are given in equations (14) and (13), respectively. $\mathrm{d}$ is the optimal lag length of the transition variable $Z_{t-d}$. The testing statistics are adopted in the Wald test, and the specification of the testing statistics is listed in equation (15).

Table 4. Model specifications for the LSTVECM vs. ESTVECM

\begin{tabular}{|c|c|c|c|c|c|c|}
\hline d & $\mathrm{H}_{04}$ F Stat & p-value & $\mathrm{H}_{03}$ F Stat & p-value & $\mathrm{H}_{02}$ F Stat & p-value \\
\hline \multicolumn{7}{|c|}{ Panel A: US REIT and stock indices } \\
\hline \multicolumn{7}{|c|}{ EQUITY REITs and S\&P 500} \\
\hline 1 & 15.2744 & 0.0093 & 12.6248 & 0.0272 & 35.0319 & 0.0000 \\
\hline 2 & 10.8782 & 0.0538 & 14.5147 & 0.0127 & 28.7953 & 0.0000 \\
\hline 3 & 14.5798 & 0.0123 & 20.8810 & 0.0009 & 23.2635 & 0.0003 \\
\hline 4 & 16.1054 & 0.0065 & 13.1231 & 0.0223 & 28.0279 & 0.0000 \\
\hline 5 & 12.0443 & 0.0342 & 7.5312 & 0.1840 & 33.6915 & 0.0000 \\
\hline 6 & 7.6428 & 0.1771 & 7.0586 & 0.2163 & 29.2438 & 0.0000 \\
\hline \multicolumn{7}{|c|}{ HYBRID REITs and S\&P 500} \\
\hline 1 & 2.2000 & 0.6991 & 16.0930 & 0.0029 & 35.3051 & 0.0000 \\
\hline 2 & 1.0201 & 0.9067 & 9.5120 & 0.0500 & 20.7075 & 0.0004 \\
\hline 3 & 23.9905 & 0.0001 & 16.9458 & 0.0020 & 21.1017 & 0.0003 \\
\hline 4 & 30.3724 & 0.0000 & 8.7520 & 0.0676 & 12.7093 & 0.0128 \\
\hline 5 & 9.0083 & 0.0609 & 8.9606 & 0.0621 & 10.4322 & 0.0337 \\
\hline 6 & 29.4803 & 0.0000 & 42.0122 & 0.0000 & 18.3910 & 0.0010 \\
\hline \multicolumn{7}{|c|}{ MORTGAGE REITs and S\&P 500} \\
\hline 1 & 1.8769 & 0.8659 & 17.8870 & 0.0031 & 13.6217 & 0.0182 \\
\hline 2 & 2.2706 & 0.8106 & 30.3425 & 0.0000 & 4.7924 & 0.4417 \\
\hline 3 & 3.4165 & 0.6361 & 34.3194 & 0.0000 & 4.7924 & 0.4417 \\
\hline 4 & 5.2118 & 0.3906 & 25.6019 & 0.0001 & 6.2242 & 0.2850 \\
\hline 5 & 6.4103 & 0.2683 & 18.9551 & 0.0020 & 7.4856 & 0.1870 \\
\hline 6 & 6.6775 & 0.2457 & 18.2100 & 0.0027 & 5.3921 & 0.3699 \\
\hline \multicolumn{7}{|c|}{ Panel B: Australian REIT and stock indices } \\
\hline 1 & 8.8987 & 0.1132 & 12.2584 & 0.0314 & 9.2428 & 0.0998 \\
\hline 2 & 7.2378 & 0.2036 & 11.3245 & 0.0453 & 10.0185 & 0.0747 \\
\hline 3 & 7.3265 & 0.1975 & 12.5237 & 0.0283 & 9.7419 & 0.0829 \\
\hline 4 & 12.7768 & 0.0256 & 12.0983 & 0.0335 & 9.8982 & 0.0782 \\
\hline 5 & 12.4598 & 0.0290 & 11.9163 & 0.0360 & 11.1160 & 0.0491 \\
\hline 6 & 10.1613 & 0.0708 & 13.3223 & 0.0205 & 10.9776 & 0.518 \\
\hline \multicolumn{7}{|c|}{ Panel C: US and Australian REIT indices } \\
\hline $\bar{d}$ & Ho4 F Stat & p-value & Ho3 F Stat & $p$-value & Ho2 F Stat & p-value \\
\hline 1 & 44.2362 & 0.0000 & 19.9909 & 0.0028 & 18.2500 & 0.0056 \\
\hline 2 & 33.3460 & 0.0000 & 43.8039 & 0.0000 & 33.0793 & 0.0000 \\
\hline 3 & 28.8012 & 0.0001 & 38.1381 & 0.0000 & 21.9706 & 0.0012 \\
\hline 4 & 17.7946 & 0.0068 & 41.2468 & 0.0000 & 29.7229 & 0.0000 \\
\hline 5 & 14.1071 & 0.0285 & 49.0795 & 0.0000 & 29.4949 & 0.0000 \\
\hline 6 & 17.1959 & 0.0086 & 24.9869 & 0.0003 & 12.8696 & 0.0452 \\
\hline
\end{tabular}

Notes: Null hypothesis of the nonlinear model specification for the LSTVECM versus the ESTVECM is given in equation (16). $\mathrm{d}$ is the optimal lag length of the transition variable $Z_{t-d}$. The testing statistics are adopted in the Wald test, and the specification of the testing statistics is given in equation (15). 
500 indices and between the US and Australian REIT indices, as well as for $d=5$ between the RETI and stock indices in Australia. These results indicate that the LSTVECM is a more appropriate model. However, $H_{03}$ is rejected for $d=1$ between Hybrid REIT and the S\&P 500 indices and for $d=3$ between Mortgage REIT and the S\&P 500 indices, which indicates that the ESTVAR and ESTVECM are more appropriate models.

Tables 5.1 and 5.2 show, respectively, the short-run dynamic STVECM-GARCH (or STVAR-GARCH) estimation results for various types of US REIT and stock index returns, Australian REIT and stock index returns and US and Australian REIT index returns. The estimated parameters, $\psi_{2}, \delta_{2}$ or $\rho$ of STVECM-GARCH (STVAR-GARCH), show that the previous messages from every type of US REIT and stock indices, Australian REIT and stock indices and US and Australian REIT indices all have significant impact on index volatility either individually or collectively. The results of the STVECM (or STVAR) in Tables 5.1 and 5.2 consistently show positive $\gamma$ smooth parameters and most of them are significantly large, meaning that there is a quick transition from one regime to another. The estimated results of the smooth transition functions in the dynamics between the REIT and corresponding stock indices in the US and Australia as well as between the two REIT indices are listed in equations (17) to (21) below. These results further confirm that the smooth transition functions between Hybrid REIT and stock indices and between Mortgage REIT and stock indices follow the exponential transition type, while those between Equity REIT and stock indices, between REIT and stock indices in the Australia and between the REIT indices in the US and Australia follow the logistic transition type. The transition function between Equity REIT and the S\&P500 indices in equation (17) is estimated as follows:

$$
\begin{aligned}
& F\left(Z_{t-1} \mid \gamma, \tau\right)= \\
& =\left\{1+\exp \left[-39.655\left(Z_{t-1}-0.151\right)\right]\right\}^{-1}, \\
& F\left(Z_{t-1} \mid \gamma, \tau\right)= \\
& =\left\{1+\exp \left[-3.662\left(Z_{t-1}-0.058\right)\right]\right\}^{-1} .
\end{aligned}
$$

The transition function between Mortgage REIT and the S\&P500 indices in equation (18) is estimated as follows:

$$
\begin{aligned}
& F\left(\Delta r_{t-1} \mid \gamma, \tau\right)= \\
& =\left\{1-\exp \left[-392.258\left(\Delta r_{t-1}-0.070\right)^{2}\right]\right\}, \\
& F\left(\Delta r_{t-1} \mid \gamma, \tau\right)= \\
& =\left\{1-\exp \left[-31.536\left(\Delta r_{t-1}-0.035\right)^{2}\right]\right\} .
\end{aligned}
$$

The transition function between Hybird REIT and the S\&P500 indices in equation (19) is estimated as follows:

$$
\begin{aligned}
& F\left(Z_{t-3} \mid \gamma, \tau\right)= \\
& =\left\{1-\exp \left[-1.258\left(Z_{t-3}-0.199\right)^{2}\right]\right\} \\
& F\left(Z_{t-3} \mid \gamma, \tau\right)= \\
& =\left\{1-\exp \left[-6.583\left(Z_{t-3}-0.254\right)^{2}\right]\right\}
\end{aligned}
$$

The transition function between Australian REIT and the ASX stock indices in equation (20) is estimated as follows:

$$
\begin{aligned}
& F\left(Z_{t-5} \mid \gamma, \tau\right)= \\
& =\left\{1+\exp \left[-844.465\left(Z_{t-5}+0.040\right)\right]\right\}^{-1} \\
& F\left(Z_{t-5} \mid \gamma, \tau\right)= \\
& =\left\{1+\exp \left[-34.092\left(Z_{t-5}+0.062\right)\right]\right\}^{-1}
\end{aligned}
$$

The transition function between US REIT and Australian REIT indices in equation (21) is estimated as follows:

$$
\begin{aligned}
& F\left(Z_{t-1} \mid \gamma, \tau\right)= \\
& =\left\{1+\exp \left[-15.435\left(Z_{t-1}+0.159\right)\right]\right\}^{-1},
\end{aligned}
$$




$$
\begin{aligned}
& F\left(Z_{t-1} \mid \gamma, \tau\right)= \\
& =\left\{1+\exp \left[-8.129\left(Z_{t-1}-0.072\right)\right]\right\}^{-1} .
\end{aligned}
$$

The $Z_{t-1}$ coefficients of Mortgage REIT (S\&P 500 stock) indices in the US with large negative and positive deviations are all $-1.470(-0.331)$. The $Z_{t-1}$ coefficients of Equity REIT (S\&P 500 stock) indices in the US with large negative and positive deviations are -1.109 (1.724) and -0.009 (0.036), respectively. The $Z_{t-1}$ coefficients of the REIT (ASX stock) indices in Australia with large nega- tive and positive deviations are $0.126(-0.076)$ and 0.125 (-0.456), respectively. The $Z_{t-1}$ coefficients of the US REIT (Australian REIT) indices with large negative and positive deviations are -0.051 (20.039) and $3.211(-0.744)$, respectively. These results indicate that there are consistently quick and evident mean reversions to the equilibrium for large negative and positive deviations between each type of REIT and stock indices in the US, between REIT and stock indices in the Australia and between the US and Australian REIT indices. More specifically, regardless of whether large positive deviations (i.e., when the S\&P 500 indi-

\begin{tabular}{|c|c|c|c|c|c|c|c|}
\hline \multicolumn{2}{|c|}{ Items } & \multicolumn{2}{|c|}{ Equity REIT and stock indices } & \multicolumn{2}{|c|}{ Hybrid REIT and stock indices } & \multicolumn{2}{|c|}{$\begin{array}{l}\text { Mortgage REIT and stock } \\
\text { indices }\end{array}$} \\
\hline \multicolumn{2}{|c|}{ Models } & \multicolumn{2}{|c|}{ LSTVECM-GARCH } & \multicolumn{2}{|c|}{ ESTVAR-GARCH } & \multicolumn{2}{|c|}{ ESTVECM-GARCH } \\
\hline \multicolumn{2}{|c|}{ Mean equations } & $\Delta p_{t}^{h}$ & $\Delta p_{t}^{s}$ & $\Delta p_{t}^{h}$ & $\Delta p_{t}^{s}$ & $\Delta p_{t}^{h}$ & $\Delta p_{t}^{s}$ \\
\hline Constant & $\alpha_{0}$ & $\begin{array}{l}-0.545 \\
\left(-1.810^{* *}\right)\end{array}$ & $\begin{array}{l}0.228 \\
(0.225)\end{array}$ & $\begin{array}{c}0.058 \\
\left(3.732^{* * *}\right)\end{array}$ & $\begin{array}{c}0.037 \\
(2.382 *)\end{array}$ & $\begin{array}{c}0.101 \\
\left(3.982^{* * *}\right)\end{array}$ & $\begin{array}{c}0.053 \\
\left(2.168^{* * *}\right)\end{array}$ \\
\hline$z_{t-1}$ & $\alpha_{1}$ & $\begin{array}{l}-1.109 \\
\left(-1.927^{* *}\right)\end{array}$ & $\begin{array}{c}1.724 \\
(0.675)\end{array}$ & & & $\begin{array}{l}-0.012 \\
(-0.207)\end{array}$ & $\begin{array}{l}0.079 \\
(1.000)\end{array}$ \\
\hline$\Delta p_{t-1}^{h}$ & $\alpha_{2}$ & $\begin{array}{c}0.239 \\
\left(4.357^{* * *}\right)\end{array}$ & $\begin{array}{l}-0.357 \\
(-0.318)\end{array}$ & $\begin{array}{l}0.035 \\
(1.861 *)\end{array}$ & $\begin{array}{l}0.006 \\
(0.660)\end{array}$ & $\begin{array}{l}0.140 \\
(-0.207)\end{array}$ & $\begin{array}{l}0.005 \\
(0.402)\end{array}$ \\
\hline$\Delta p_{t-1}^{s}$ & $\alpha_{3}$ & $\begin{array}{c}0.019 \\
(0.672)\end{array}$ & $\begin{array}{l}2.447 \\
(0.474)\end{array}$ & $\begin{array}{l}-0.017 \\
(-1.334)\end{array}$ & $\left(-0.0477^{* * *}\right)$ & $\begin{array}{l}-0.017 \\
(-0.737)\end{array}$ & $\begin{array}{l}-0.051 \\
\left(-2.126^{* *}\right)\end{array}$ \\
\hline Constant & $\beta_{0}$ & $\begin{array}{c}0.640 \\
\left(2.111^{* * *}\right)\end{array}$ & $\begin{array}{l}-0.192 \\
(-0.186)\end{array}$ & $\begin{array}{l}-4.971 \\
(-0.003)\end{array}$ & $\begin{array}{l}2.684 \\
(0.001)\end{array}$ & $\begin{array}{l}-1.202 \\
\left(-2.533^{* *}\right)\end{array}$ & $\begin{array}{l}-0.134 \\
(-0.960)\end{array}$ \\
\hline$z_{t-1}$ & $\beta_{1}$ & $\begin{array}{l}1.100 \\
\left(1.768^{*}\right)\end{array}$ & $\begin{array}{l}-1.688 \\
(-0.643)\end{array}$ & & & $\begin{array}{l}-1.458 \\
(-2.456 * *)\end{array}$ & $\begin{array}{l}-0.410 \\
\left(-2.751^{* * *}\right)\end{array}$ \\
\hline$\Delta p_{t-1}^{h}$ & $\beta_{2}$ & $\begin{array}{l}-0.237 \\
\left(-3.944^{* * *}\right)\end{array}$ & $\begin{array}{l}0.368 \\
(0.326)\end{array}$ & $\begin{array}{l}-0.323 \\
(-0.005)\end{array}$ & $\begin{array}{l}0.537 \\
(0.006)\end{array}$ & $\begin{array}{l}-1.637 \\
\left(-3.037^{* * *}\right)\end{array}$ & $\begin{array}{l}-0.066 \\
(-1.505)\end{array}$ \\
\hline$\Delta p_{t-1}^{s}$ & $\beta_{3}$ & $\begin{array}{l}-0.057 \\
(-1.605)\end{array}$ & $\begin{array}{l}-2.544 \\
(-0.492)\end{array}$ & $\begin{array}{l}-1.937 \\
(-0.015)\end{array}$ & $\begin{array}{c}0.688 \\
(0.002)\end{array}$ & $\begin{array}{c}0.010 \\
(0.033)\end{array}$ & $\begin{array}{c}0.011 \\
(0.180)\end{array}$ \\
\hline $\begin{array}{l}\text { Transition } \\
\text { speed }\end{array}$ & $\gamma$ & $\begin{array}{l}39.655 \\
(1.344)\end{array}$ & $\begin{array}{l}3.662 \\
(1.109)\end{array}$ & $\begin{array}{c}392.258 \\
(0.122)\end{array}$ & $\begin{array}{l}31.536 \\
(0.105)\end{array}$ & $\begin{array}{c}1.258 \\
\left(3.858^{* * *}\right)\end{array}$ & $\begin{array}{c}6.583 \\
\left(1.655^{*}\right)\end{array}$ \\
\hline $\begin{array}{l}\text { Threshold } \\
\text { parameter }\end{array}$ & $\tau$ & $\begin{array}{c}0.151 \\
(1.559) \\
\end{array}$ & $\begin{array}{c}0.058 \\
\left(2.383^{* *}\right) \\
\end{array}$ & $\begin{array}{c}0.070 \\
(0.030) \\
\end{array}$ & $\begin{array}{c}0.035 \\
(0.053) \\
\end{array}$ & $\begin{array}{c}0.199 \\
\left(3.038^{* * *}\right) \\
\end{array}$ & $\begin{array}{c}0.254 \\
\left(1.715^{*}\right) \\
\end{array}$ \\
\hline \multicolumn{2}{|c|}{$\begin{array}{c}\text { Variance and } \\
\text { covariance } \\
\text { equations }\end{array}$} & $h_{h, t}$ & $h_{s, t}$ & $h_{h, t}$ & $h_{s, t}$ & $h_{h, t}$ & $h_{s, t}$ \\
\hline Constant & $\phi_{0}, \delta_{0}$ & $\begin{array}{c}0.028 \\
\left(6.961^{* * *}\right)\end{array}$ & $\begin{array}{c}0.0106 \\
\left(4.481^{* * *}\right)\end{array}$ & $\begin{array}{c}0.028 \\
\left(64.243^{* * *}\right)\end{array}$ & $\begin{array}{c}0.010 \\
\left(73.310^{* * *}\right)\end{array}$ & $\begin{array}{c}0.066 \\
\left(13.627^{* * *}\right)\end{array}$ & $\begin{array}{c}0.009 \\
\left(13.826^{* * *}\right)\end{array}$ \\
\hline$\varepsilon_{h, t-1}^{2}, \varepsilon_{s, t-1}^{2}$ & $\phi_{1}, \delta_{1}$ & $\begin{array}{c}0.126 \\
\left(12.138^{* * *}\right)\end{array}$ & $\begin{array}{c}0.065 \\
\left(10.335^{* * *}\right)\end{array}$ & $\begin{array}{c}0.121 \\
\left(13.632^{* * *}\right)\end{array}$ & $\begin{array}{c}0.064 \\
\left(88.386^{* * *}\right)\end{array}$ & $\begin{array}{c}0.170 \\
\left(19.448^{* * *}\right)\end{array}$ & $\begin{array}{c}0.065 \\
\left(39.312^{* * *}\right)\end{array}$ \\
\hline$h_{h, t-1}, h_{s, t-1}$ & $\phi_{2}, \delta_{2}$ & $\begin{array}{c}0.856 \\
\left(70.041^{* * *}\right)\end{array}$ & $\begin{array}{c}0.928 \\
\left(79.782^{* * *}\right)\end{array}$ & $\begin{array}{c}0.860 \\
\left(114.558^{* *}\right)\end{array}$ & $\begin{array}{c}0.929 \\
\left(504.577^{* * *}\right)\end{array}$ & $\begin{array}{c}0.818 \\
\left(101.352^{* * *}\right)\end{array}$ & $\begin{array}{c}0.930 \\
\left(602.021^{* * *}\right)\end{array}$ \\
\hline$h_{h . s, t}$ & $\rho$ & \multicolumn{2}{|c|}{$\begin{array}{c}0.620 \\
\left(61.112^{* * *}\right)\end{array}$} & \multicolumn{2}{|c|}{$\begin{array}{c}0.498 \\
\left(36.971^{* * *}\right)\end{array}$} & \multicolumn{2}{|c|}{$\begin{array}{c}0.485 \\
\left(47.410^{* * *}\right)\end{array}$} \\
\hline
\end{tabular}

Table 5.1. Estimated results of models in US REIT and US stock indices

Notes: The specifications of the STVECM and VECM are given in equation (9). The numbers in ( ) indicate the t-statistics. ${ }^{* * *}$ ${ }^{*}$ and ${ }^{*}$ denote significance at the $1 \%, 5 \%$ and $10 \%$ levels, respectively. 
Table 5.2. Estimated results of models of Australian REIT and stock indices and US REIT and Australian REIT indices

\begin{tabular}{|c|c|c|c|c|c|}
\hline \multicolumn{2}{|l|}{ Items } & \multicolumn{2}{|c|}{ Australian REIT and stock indices } & \multicolumn{2}{|c|}{ US REIT and Australian REIT indices } \\
\hline \multirow{2}{*}{\multicolumn{2}{|c|}{$\begin{array}{c}\text { Models } \\
\text { Mean equations }\end{array}$}} & \multicolumn{2}{|c|}{ LSTVECM-GARCH } & \multicolumn{2}{|c|}{ LSTVECM-GARCH } \\
\hline & & $\Delta p_{t}^{h}$ & $\Delta p_{t}^{s}$ & $\Delta p_{t}^{h 1}$ & $\Delta p_{t}^{h 2}$ \\
\hline Constant & $\alpha_{0}$ & $\begin{array}{c}0.122 \\
\left(10.620^{* * *}\right)\end{array}$ & $\begin{array}{c}0.024 \\
\left(2.211^{* *}\right)\end{array}$ & $\begin{array}{c}0.092 \\
\left(4.210^{* * *}\right)\end{array}$ & $\begin{array}{l}11.733 \\
(0.847)\end{array}$ \\
\hline$z_{t-1}$ & $\alpha_{1}$ & $\begin{array}{c}0.126 \\
\left(2.623^{* * *}\right)\end{array}$ & $\begin{array}{l}-0.076 \\
(-1.799 *)\end{array}$ & $\begin{array}{l}-0.051 \\
(-0.293)\end{array}$ & $\begin{array}{l}20.039 \\
(0.867)\end{array}$ \\
\hline$\Delta p_{t-1}^{h}$ & $\alpha_{2}$ & $\begin{array}{l}0.004 \\
(0.261)\end{array}$ & $\begin{array}{l}-0.0085 \\
(-0.675)\end{array}$ & $\begin{array}{c}0.020 \\
(0.864)\end{array}$ & $\begin{array}{l}-0.467 \\
(-0.732)\end{array}$ \\
\hline$\Delta p_{t-1}^{s}$ & $\alpha_{3}$ & $\begin{array}{c}0.017 \\
(0.988)\end{array}$ & $\begin{array}{l}-0.010 \\
(-0.572)\end{array}$ & $\begin{array}{l}-0.030 \\
(-0.989)\end{array}$ & $\begin{array}{c}0.858 \\
(0.894)\end{array}$ \\
\hline Constant & $\beta_{0}$ & $(-0.100$ & $\begin{array}{c}0.254 \\
\left(10.066^{* * *}\right)\end{array}$ & $\begin{array}{c}-0.516 \\
\left(-1.928^{*}\right)\end{array}$ & $\begin{array}{l}-11.779 \\
(-0.848)\end{array}$ \\
\hline$z_{t-1}$ & $\beta_{1}$ & $\begin{array}{l}-0.001 \\
(-0.014)\end{array}$ & $\begin{array}{l}-0.380 \\
\left(-4.405^{* * *}\right)\end{array}$ & $\begin{array}{c}3.262 \\
(1.681)\end{array}$ & $\begin{array}{l}-19.295 \\
(-0.840)\end{array}$ \\
\hline$\Delta p_{t-1}^{h}$ & $\beta_{2}$ & $\begin{array}{l}0.032 \\
(1.553)\end{array}$ & $\begin{array}{c}0.063 \\
\left(1.981^{* * *}\right)\end{array}$ & $\begin{array}{c}-0.434 \\
\left(-5.421^{* * *}\right)\end{array}$ & $\begin{array}{l}0.674 \\
(1.055)\end{array}$ \\
\hline$\Delta p_{t-1}^{s}$ & $\beta_{3}$ & $\begin{array}{c}-0.124 \\
\left(-6.665^{* * *}\right)\end{array}$ & $\begin{array}{c}-0.128 \\
\left(-3.1636^{* * *}\right)\end{array}$ & $\begin{array}{l}0.237 \\
(1.508)\end{array}$ & $\begin{array}{l}-0.945 \\
(-0.980)\end{array}$ \\
\hline Transition speed & $\gamma$ & $\begin{array}{c}844.465 \\
(1.607)\end{array}$ & $\begin{array}{c}34.092 \\
\left(15.720^{* * *}\right)\end{array}$ & $\begin{array}{l}15.435 \\
(0.197)\end{array}$ & $\begin{array}{c}8.129 \\
\left(3.153^{* *}\right)\end{array}$ \\
\hline Threshold parameter & $\tau$ & $\begin{array}{l}-0.040 \\
(-1.199) \\
\end{array}$ & $\begin{array}{c}-0.062 \\
\left(-13.652^{* * *}\right) \\
\end{array}$ & $\begin{array}{c}-0.159 \\
\left(-4.401^{* * *}\right) \\
\end{array}$ & $\begin{array}{c}0.072 \\
\left(5.713^{* * *}\right) \\
\end{array}$ \\
\hline \multicolumn{2}{|c|}{$\begin{array}{c}\text { Variance and covariance } \\
\text { equations }\end{array}$} & $h_{h, t}$ & $h_{s, t}$ & $h_{h, t}$ & $h_{s, t}$ \\
\hline Constant & $\phi_{0}, \delta_{0}$ & $\begin{array}{c}0.013 \\
\left(13.179^{* * *}\right)\end{array}$ & $\begin{array}{c}0.012 \\
\left(15.204^{* * *}\right)\end{array}$ & $\begin{array}{c}0.027 \\
\left(4.728^{* * *}\right)\end{array}$ & $\begin{array}{c}0.014 \\
\left(4.680^{* * *}\right)\end{array}$ \\
\hline$\varepsilon_{h, t-1}^{2}, \varepsilon_{s, t-1}^{2}$ & $\phi_{1}, \delta_{1}$ & $\begin{array}{c}0.087 \\
\left(51.512^{* * *}\right)\end{array}$ & $\begin{array}{c}0.087 \\
\left(41.669^{* * *}\right)\end{array}$ & $\begin{array}{c}0.144 \\
\left(10.119^{* * *}\right)\end{array}$ & $\begin{array}{c}0.098 \\
\left(8.798^{* * *}\right)\end{array}$ \\
\hline$h_{h, t-1}, h_{s, t-1}$ & $\phi_{2}, \delta_{2}$ & $\begin{array}{c}0.901 \\
\left(566.770^{* *}\right)\end{array}$ & $\begin{array}{c}0.897 \\
\left(501.108^{* *}\right)\end{array}$ & $\begin{array}{c}0.858 \\
\left(70.041^{* * *}\right)\end{array}$ & $\begin{array}{c}0.890 \\
\left(79.782^{* * *}\right)\end{array}$ \\
\hline$h_{h . s, t}, h_{h 1 . h 2, t}$ & $\rho$ & \multicolumn{2}{|c|}{$\begin{array}{c}0.534 \\
\left(51.158^{* * *}\right)\end{array}$} & \multicolumn{2}{|c|}{$\begin{array}{c}0.122 \\
\left(6.369^{* * *}\right)\end{array}$} \\
\hline
\end{tabular}

Notes: the specifications of the STVECM and VECM are given in equation (9). The numbers in ( ) indicate the t-statistics. ${ }^{* * *}$, ${ }^{*}$ and ${ }^{*}$ denote significance at the $1 \%, 5 \%$ and $10 \%$ levels, respectively.

ces are significantly higher than Mortgage REIT indices), or large negative deviations exist (when the S\&P 500 indices are significantly lower than Mortgage REIT indices), the adjustment speed of the US S\&P 500 indices reversion to equilibrium is greater than that of the Mortgage REIT indices. This may be the reason why investors who simultaneously invest in US Mortgage REITs and S\&P 500 stocks prefer to purchase stocks that offer higher returns, so they purchase stocks more frequently than REITs, pushing the corresponding stock prices back to equilibrium at a faster speed than REIT prices. Moreover, when the S\&P 500 indices are significantly higher than Equity REIT indices (i.e., when there are large positive deviations), the informed traders tend to buy the relatively cheaper Equity REITs. In this case, the incentive to purchase Equity REITs will increase, thus accelerating the adjustment speed of Equity REITs indices reverting to equilibrium. However, when the S\&P 500 indices are significantly lower than Equity REITs indices (i.e., when there are large negative deviations), investors tend to purchase Equity REITs that may offer lower risks and more stable returns, thus pushing the adjustment speed of Equity REITs indices reverting to equilibrium faster than that of their corresponding stock indices. In addition, when Australian common 
stock indices are significantly higher (lower) than its REIT indices (i.e., when there are large positive (negative) deviations), informed traders tend to buy the relatively cheaper REITs (stocks), thus pushing the adjustment speed of REIT (stock) indices reverting to equilibrium faster than that of their corresponding stock (REIT) indices. When US REITs indices are significantly higher (lower) than Australian REIT indices (i.e., when there are large positive (negative) deviations), the informed traders tend to buy relatively cheaper Australian REITs (US REITs), thus pushing the adjustment speed of Australian REIT (US REIT) indices reverting to equilibrium faster than that of US REIT (Australian REIT) indices.

Moreover, the adjustment speeds of US Mortgage REIT and the S\&P 500 indices reverting to equilibrium from large positive or negative deviations are equal, and this may be the reason why the nature of the Mortgage REITs is very similar to that of bonds. Since investments in the Mortgage REITs and S\&P 500 stocks are made to diversify the risk of changes in interest rates, investors of both Mortgage REITs and S\&P 500 stocks have developed very rigid investment habits. Thus, regardless of whether there is a large positive deviation (i.e., stock indices are significantly higher than REIT indices) or a large negative deviation (i.e., stock indices are significantly lower than REIT indices), investors of Mortgage REITs and
S\&P 500 stocks basically do not have the incentive to change their investment behavior, resulting in the equal adjustment speeds of Mortgage REIT and S\&P 500 indices when reverting to equilibrium. However, the speeds of adjustment in reverting to equilibrium of the large positive and negative deviations between US Equity REIT and S\&P 500 indices, between Australian REIT and ASX stock indices, or between US REIT and Australia REIT indices are unequal, and this may be the reason why the nature of Equity REITs is relatively similar to that of stocks, resulting in the possibility that investors' incentives to invest in these REITs and stocks are easy to change.

According to the theoretical models of the interaction between arbitrageurs and noise traders, noise traders further drove prices to show their persistency when there were small deviations. On the contrary, when there are large deviations, the arbitrageurs will be more confident in driving the market in the appropriate direction and price movements will quickly revert to equilibrium. Moreover, this study demonstrates that the ESTVECM is fitted for describing the short-run return dynamics of the deviations from the co-movement equilibrium between Mortgage REIT and S\&P 500 stock prices in the US, while the LSTVECM is more suitable for describing those between Equity REIT and S\&P 500 stock prices in the US, between the REIT and ASX stock prices in the Australia and

Table 6. Results of the nonlinear Granger causality test

\begin{tabular}{|c|c|c|}
\hline \multicolumn{3}{|c|}{ Panel A: US Equity REIT and stock indices } \\
\hline \multicolumn{3}{|c|}{ Equity REIT and stock indices } \\
\hline Large positive deviation & $(-0.900)$ & $\left(3.617^{* * *}\right)$ \\
\hline Large negative deviation & $(-1.149)$ & $\left(2.191^{* *}\right)$ \\
\hline \multicolumn{3}{|c|}{ Hybrid REIT and stock indices } \\
\hline Large positive deviation & $(0.759)$ & $\left(2.459^{* * *}\right)$ \\
\hline Large negative deviation & $(-0.597)$ & $\left(2.300^{* *}\right)$ \\
\hline \multicolumn{3}{|c|}{ Mortgage REIT and stock indices } \\
\hline Large positive deviation & $(-0.160)$ & $\left(3.374^{* * *}\right)$ \\
\hline Large negative deviation & $(0.932)$ & $(3.450 * * *)$ \\
\hline \multicolumn{3}{|c|}{ Panel B: Australian REIT and stock indices } \\
\hline Large positive deviation & $(1.312 *)$ & $(1.643 *)$ \\
\hline Large negative deviation & $\left(4.14^{* * *}\right)$ & $\left(4.802^{* * *}\right)$ \\
\hline \multicolumn{3}{|c|}{ Panel C: US and Australian REIT indices } \\
\hline Large positive deviation & $(0.079)$ & $\left(3.55^{* * *}\right)$ \\
\hline Large negative deviation & $(-0.21)$ & $\left(2.516^{* *}\right)$ \\
\hline
\end{tabular}

Notes: The numbers in ( ) indicate the t-statistics. ${ }^{* *},{ }^{* *}$ and ${ }^{*}$ denote significance at the $1 \%, 5 \%$ and $10 \%$ levels, respectively. 
between the US and Australian REIT prices. That is, the adjustment speeds between Mortgage REIT and S\&P 500 stock prices in the US reverting to equilibrium for the large positive and negative deviations are all equal, while those between Equity REIT and S\&P 500 stock prices in the US, between the REIT and ASX stock prices in the Australia and between the two REIT prices in the US and Australia are unequal.

As seen in Table 6 (above), the REIT prices significantly influence the stock prices, regardless of whether there are large positive or negative deviations (or returns) in STVECM (or STVAR) between US REITs and stock indices. This may be due to the possibility that REIT markets in the US have the largest market capitalization in the world and more mature investment environments for investors compared to those in other countries. Thus, when the US REIT prices rise, the value of REITs held by American companies will also increase, which pushes up the market capitalization of US enterprises, as well as stock prices. Meanwhile, by putting their REITs on mortgages, American investors can borrow more money to invest and stimulate the stock market, thus raising stock prices. Hence, it is confirmed that the 'credit price effect' can commonly exist in the US. In other words, in terms of price discovery, the US REIT markets are more important than the stock markets. Nevertheless, both 'credit price effect' (in which REIT prices clearly influence stock prices) and 'wealth effect' (in which stock prices influence REIT prices) are found in Australia. This may be due to the possibility that Australian REITs and stock markets have equal powers that influence one another. Similarly, US REIT indices significantly influence Australian REIT indices, which show that price discovery is more important in the US REIT market than the Australian REIT market.

\section{CONCLUSION}

This study utilized the co-integration test with structural breaks proposed by Gregory and Hansen (1996) in order to test whether non-linear co-integration relationships exist between US REITs and stock indices, between Australian REIT and stock indices and between US REITs and Australian REIT indices. Moreover, we used a GARCH-included STVECM to separately explore the adjustment efficiencies of the US and Australian REIT and corresponding stock prices, as well as the two countries' REIT prices when there are deviations in long-run equilibrium between the US and Australian REIT indices. Furthermore, this study used the non-linear Granger causality test mentioned by Hiemstra and Jones (1994) to analyze whether 'wealth effect' (in which stock prices influence REIT prices) or 'credit price effect' (in which REIT prices influence stock prices) exists in the US and Australian markets. We also attempted to discover where a price discovery function existed in the US or Australian REIT markets. Our results showed that there are non-linear structural break co-integration relationships between the US Equity and Mortgage REIT indices and corresponding stock indices, between Australian REIT and stock indices and between the US and Australian REIT indices, respectively. Moreover, the results of a non-linear Granger causality test found that there is a credit price effect in which the various types of US REIT indices influence stock indices regardless of whether large positive or negative deviations (or returns) in STVECM (or STVAR) occur. Nevertheless, the so-called credit price effect and the wealth effect simultaneously exist in Australian REIT and stock markets. In addition, the price discovery function is more important in the US REIT market than the Australian REIT market.

In sum, the return dynamics governing the small deviations were obviously different from those governing the large deviations. Furthermore, our results showed that in order to diversify the risk of changes in interest rates, investors included rigid habits in investing toward bond-type US Mortgage REITs and S\&P 500 stocks. As a result, their adjustment speeds when reverting to equilibrium had a tendency to be equal when there were large positive or negative deviations. However, the REITs investments in US Equity REIT and stock indices, Australian REIT and stock indices and the US and Australian REIT indices were mainly stock-type Equity REITs of which the investors were more likely to change their investing incentives. Therefore, the short-run adjustment speeds when reverting to equilibrium for 
the large negative and positive deviations were unequal. Specifically speaking, when large positive and negative deviations from the equilibrium between US Mortgage REIT and S\&P 500 stock indices exist, the adjustment speed of stock indices reverting to equilibrium was greater than that of REIT indices. Meanwhile, the adjustment speed of US Equity REIT and S\&P 500 indices when reverting to equilibrium for large negative and positive deviations was different, but the adjustment speed of Equity REIT indices when reverting to equilibrium was greater than that of stock indices. However, when there was a large positive deviation in the Australian REIT and stock indices, the adjustment speed of the REIT indices when reverting to equilibrium was faster than that of corresponding stock indices. In this case, when there was a large negative deviation, this conclusion is reversed.

Contributions toward this paper include the following. We use a model that allowed the time-series variables to exist in the structural breaks and the self-decided structure break point to examine whether the non-linear co-integration with structural breaks exists between the US and Australia REIT indices and corresponding stock indices, as well as between the respective REIT indices. Moreover, we confirm that STVECM with GARCH can be applied to analyze the efficiency of short-run dynamic adjustment in mean reversion when there are deviations from the equilibrium between the US, Australian REIT and corresponding stock indices and between the US and Australian REIT indices, respectively. On the one hand, the STVECM used by this study confirms that the US S\&P 500 index plays the main role when reverting to equilibrium between Mortgage REIT and corresponding stock indices, while US Equity REIT index plays the main role when reverting to equilibrium between Equity REIT and corresponding stock indices. Meanwhile, the remaining indices in the STVECM include different adjustment speeds when reverting to equilibrium when large positive and negative deviations from the equilibrium occur. On the other hand, we also confirm that credit price effects exist in each type of US REIT and the stock market regardless of whether large positive or negative deviations (or returns) occur in STVECM (or STVAR). However, there is a feedback effect between Australian REIT and stock markets, as well as a price discovery between the US REIT market and the Australian REIT market. Based on the above results and analysis, this paper can serve as an informative reference for investors planning to invest in either the US or Australia.

\section{REFERENCES}

1. Baek, E., Brock, W. (1992). A general test for nonlinear granger causality: bivariate model (Working paper). Iowa State University and University of Wisconsin, Madison.

2. Campbell, J. Y., Lo, A. W., Mackinlay, C. (1997). The econometrics of financial markets. Princeton University Press, Princeton.

3. Chau, K. W., Ma, S. M., Ho, D. C. W. (2000). The pricing of luckiness in the apartment market. Journal of Real Estate Literature, 9(1), 31-40.

4. Chen, M. C., Patel, K. (1998) House price dynamics and Granger causality: an analysis of Taipei new dwelling market. Journal of Asian Real Estate Society, 1(1), 101-126. Retrieved from http://epmesc. umac.mo/fba/irer/papers/past/ vol1_pdf/101-126UK.pdf

5. Chen, Y. (2007). Overheidsingrijpen bij Gebiedsontwikkeling van stedelijk China in verandering [State intervention in area development in transitional China]. Real Estate Magazine, 51(3), 32-37. Retrieved from http://www.realestatemagazine.nl/assets/image/artikelen/ REM51_003.pdf

6. Fu, Y., Leung, W. K., Lo, W. C. (1993). The dynamics of residential property markets and the stock market in Hong Kong. Asia-Pacific Financial and Forecasting Research Center Technical Report, 94(3).

7. Glasock, J. L., Lu, C., So, R. W. (2000). Further evidence on the integration of REIT, bond, and stock returns. The Journal of Real Estate Finance and Economics, 20(2), 177-194. Retrieved from https://link. springer.com/article/10.1023/ A\%3A1007877321475

8. Green, R. K. (2002). Stock prices and house prices in California: new evidence of a wealth effect? Regional Science and Urban Economics, 32, 775-783. https://doi.org/10.1016/S01660462(01)00103-X

9. Gregory, A. W., Hansen, B. E. (1996). Residual-based tests for cointegration in models with regime shifts. Journal of Econometrics, 70(1), 99-126. https://doi.org/10.1016/03044076(69)41685-7

10. Hiemstra, C., Jones, J. D. (1994). Testing for linear and nonlinear 
granger causality in the stock price-volume relation. The Journal of Finance 49, 1639-1664. Retrieved from http://www.jstor. org/stable/2329266

11. Hui, E. C. M., Yue, S. (2006). Housing price bubbles in Hong Kong, Beijing and Shanghai: a comparative study. Journal of Real Estate Finance and Economics, 33(4), 299. Retrieved from https:// link.springer.com/article/10.1007/ s11146-006-0335-2

12. Larson, S. (2005). Real estate investment trusts and stock price reversals. Journal of Real Estate Finance and Economics, 30, 8188. Retrieved from https://link springer.com/article/10.1007/ s11146-004-4832-x

13. Ling, D. C., Naranjo, A. (1999). The integration of commercial real estate markets and stock markets. Real Estate Economics, 27(3), 1-28. Retrieved from http:// www.blackwell-synergy.com/doi/ abs/10.1111/1540-6229.00781

14. Liow, K. H., Yang, H. (2005). Longterm co-memories and short run adjustment: securitized real estate and stock markets. Journal of Real Estate Finance and Economics, 31(3), 283-300. Retrieved from https://link.springer.com/article/10.1007/s11146-005-2790-6

15. Liu, C. H., Hartzell, D. J., Greig, W., Grissom, T. V. (1990). The integration of the real estate market and the stock market: some preliminary evidence. Journal of Real Estate Finance and Economics, 3, 261-282. Retrieved from https:// link.springer.com/article/10.1007/ BF00216190

16. Luukkonen, R., Saikkonen, P., Terasvirta, T. (1988). Testing linearity against smooth transition autoregressive models. Biometriku, 75, 491-499. https://doi. org/10.1093/biomet/75.3.491
17. Kapetanios, G., Shin, Y., Snell, A. (2003). Testing for a unit root in the nonlinear STAR framework. Journal of Econometrics, 112, 359-379. https://doi.org/10.1016/S03044076(02)00202-6

18. McMillan, D. G. (2004). Nonlinear predictability of short-run deviations in UK stock market returns. Economics Letters, 84, 149-154. https://doi.org/10.1016/j. econlet.2003.10.014

19. Markowitz, H. (1952). Portfolio selection. Journal of Finance, 8, 77-91.

20. Ong, S. E. (1995). Singapore real estate and property stocks-a cointegration test. Journal of Property Research, 12, 29-39. http://dx.doi. org/10.1080/09599919508724127

21. Okunev, J., Wilson, P., Zurbruegg, R. (2000). The causal relationship between real estate and stock markets. Journal of Real Estate and Economics, 21(3), 251-261. Retrieved from https://link. springer.com/article/10.1023/ A\%3A1012051719424

22. Okunev, J., Wilson, P., Zurbruegg, R. (2002). Relationships between Australian real estate and stock market prices a case of market inefficiency. Journal of Forecasting, 21, 181-192. https://doi. org/10.1002/for.825

23. Oppenheimer, P., Grissom, T. V. (1998). Frequency space correlation between REITs and capital market indices. Journal of Real Estate Research, 16, 291-310. Retrieved from http://pages.jh.edu/ jrer/papers/abstract/past/av16n03/ v16n3a04.htm

24. Peng, C. W., Chang, J. E. (2000). The influence of macroeconomic variables on real estate cycles in Taiwan. Proceedings of the National Science Council. Part C, Humanities and Social Sciences, 10(3), 330-343.
25. Tuluca, S., Myer, F., Webb, J. R. (2000). Dynamics of private and public real estate markets. Journal of Real Estate Finance and Economics, 21(3), 279-96. Retrieved from https://link. springer.com/article/10.1023 A\%3A1012055920332

26. Su, C. W. (2011). Non-linear causality between the stock and real estate markets of Western European countries: Evidence from rank tests. Economic Modelling, 28, 845-851. https://doi.org/10.1016/j.econmod.2010.10.021

27. Su, C. W., Chang, H. L., Zhu, M. N. (2011). A non-linear model of causality between the stock and real estate markets of European countries. Romanian Journal of Economic Forecasting, 1, 41-52. Retrieved from http://www.ipe.ro/ rjef.htm

28. Sun, Q., Tong, W. H. S., Yang, Y. (2009). Market liberalization within a country. Journal of Empirical Finance, 16, 18-41. https://doi. org/10.1016/j.jempfin.2008.07.003

29. Terasvirta, T. (1994). Specification, estimation, and evaluation of smooth transition autoregressive models. Journal of American Statistic Association, 89, 281-312. http://dx.doi.org/10.1080/01621459 1994.10476462

30. Wilson, P., Okunev, J. (1997). Using nonlinear tests to examine integration between real estate and stock markets. Real Estate Economics, 25(3), 487-503. Retrieved from http://www. blackwell-synergy.com/doi/ abs/10.1111/1540-6229.00724

31. Wilson, P., Okunev, J. (1999). Longterm dependencies and long run non-periodic co-cycles: real estate and stock markets. Journal of Real Estate Research, 18(2), 257-278. Retrieved from https://link.springer. com/article/10.1007/s11146-0052790-6 